\title{
What Makes Reform Work?-School-Based Conditions as Predictors of Teachers' Changing Practice after a National Curriculum Reform
}

\author{
Magnus R. Ramberg ${ }^{1}$ \\ ${ }^{1}$ Department of Education, Norwegian University of Science and Technology, Trondheim, Norway \\ Correspondence: Magnus R. Ramberg, Department of Education, Norwegian University of Science and \\ Technology, 7491 Trondheim, Norway. Tel: 47-9322-9428. E-mail: magnus.rye.ramberg@svt.ntnu.no
}

Received: February 24, 2014

Accepted: April 11, 2014 Online Published: May 27, 2014

doi:10.5539/ies.v7n6p46

URL: http://dx.doi.org/10.5539/ies.v7n6p46

\begin{abstract}
Educational change initiatives, whether they involve the implementation of new policies or curriculum reforms, often fail to reach the level of teachers' classroom practices. In the search for explanations, numerous studies have either characterized teachers as resistant to change or focused on how schools' workplace conditions have failed to influence teacher change. This study draws attention to these issues by investigating teachers' perceptions of the degree to which a national curriculum reform has brought about changes in their teaching. The study also proposes a model of how teachers' perceptions of school-based conditions (i.e., school leadership, teacher collaboration, and development of school-based curricula) are related to teachers' general orientations towards change and teachers' perceptions of change as a result of the reform. The participants were 738 Norwegian teachers in public primary and lower secondary schools, and the data were analyzed using descriptive data, correlation analysis and structural equation modeling (SEM). The results indicate that the overall influence of the reform on teachers' teaching was moderate. The results also revealed positive relationships between teachers' perceptions of school-based conditions, teachers' general orientations towards change and the degree of perceived reform changes in teachers' teaching. However, a surprising finding is that school leadership and teacher collaboration were only indirectly related to teachers' perceptions of reform changes, mediated through teachers' general orientations towards change. The article highlights important relationships between educational reform, school-based conditions and teachers. It also contributes knowledge that is relevant to consider for successful reform of schools and education.
\end{abstract}

Keywords: education reform, teachers' perceptions, teacher-school relationships, SEM

\section{Introduction}

A powerful image generated by studies on educational change is that of the failure of "top-down", externally mandated school reforms to reach the level of teachers' classroom practices (Cuban, 1993; Elmore, 1996; Sarason, 1990). Supported by research on the occupational norm of autonomy in teachers' work and criticism of the isolated teacher (Goodlad, 1984; Little, 1990; Lortie, 1975), the failure of external reforms across Western education systems in the 1960s and 1970s was to a large extent attributed to the view of teachers as recalcitrant and resistant to change. Teachers' classroom work, the "grammar of schooling" (Tyack \& Tobin, 1994), it was argued, remained basically untouched as teachers simply closed the classroom door to external pressures.

The failure of top-down approaches to educational change and norms of teacher individualism led to "bottom-up" approaches across educational systems in Western countries in the late 1970s. Rather than imposing external reforms on schools and teachers, school-based development initiatives flourished. The focus of the reforms involved the importance of the organisational structure and culture of schools in creating favourable conditions for change (e.g., Berg \& Wallin, 1982). With the school at the centre of change, reform strategies concentrated on the role of teacher collaboration (Little, 1982) and the role of school leadership and management in organizing for change (e.g., Fink, 1992; Louis \& Miles, 1990), as well as providing lists of what characterized effective schools (e.g., Mortimore, 1998; Rutter, 1983; Teddlie, Kirby, \& Stringfield, 1989; Teddlie \& Stringfield, 1993).

By the 1990s, there was mounting evidence that the bottom-up approachdid not affect the core of teaching and learning in schools (Fullan, 1991). Since then, reform efforts in educational policies across Western countriesover the past two decadeshave included a combination of top-down and bottom-up approaches in which 
the central system provides educational goals and support, and the actual change processes and ways of reaching the centrally mandated goals are left to local schools and teachers to decide.

In the case of Norway, evidence of more recent combinations of top-down and bottom-up approaches in education can be located in the latest national curriculum reform called The National Curriculum Reform for Knowledge Promotion, which commenced in 2006 (referred to as KP06). This reform sought to change the work of teachers by introducing centrally determined competency aims and a strong focus on how to observe pupils' learning achievements, combined with a bottom-up, school-based approach and an emphasis on teachers as key agents of change, e.g., by including teachers as co-constructors of local subject curricula. Along these lines, keeping in mind that one cannot place the burden of educational reform on teachers alone, in Norwegian educational policies it is expected that each school will create favourable school-based conditions for teachers to succeed under the demands of curriculum implementation and educational change (e.g., Official Norwegian Report 2003: 16; White Paper no. 11 (2008-2009)).

The aim of this study is to investigatehow the top-down and bottom-up approaches interact in the reform process. Specifically, the studycentres on teachers' perceptions of the degree to which the national curriculum reform KP06 has brought about changes in their teaching and proposes a model of howteachers' perceptions of central school-based conditions (i.e., school leadership, teacher collaboration, and school's development of school-based curricula)are related to teachers' general orientations towards change and their perceptions of change as a result of the reform. The analysis is based onthree research questions:

(i) To what extent has the national curriculum reform KP06 brought about changes in teaching as perceived by the teachers?

KP06

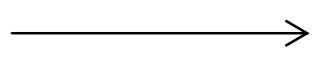

Change in practice

Figure 1. A model of research question (i)

(ii) Is there a relationship between teachers' general orientations towards change and the degree of perceived reform changes in teachers' teaching?

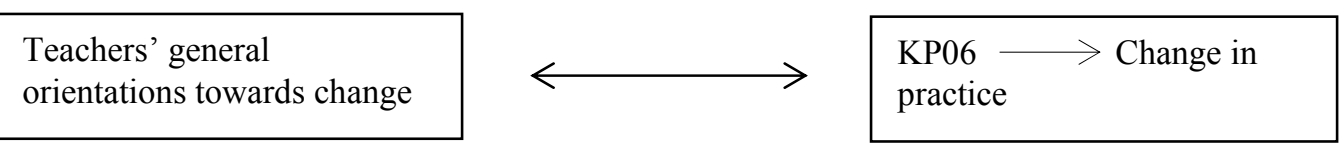

Figure 2. A model of research question (ii)

(iii) How may the perceived school-based conditions and teachers' general orientations towards change influence the degree of perceived reform changes in teachers' teaching?

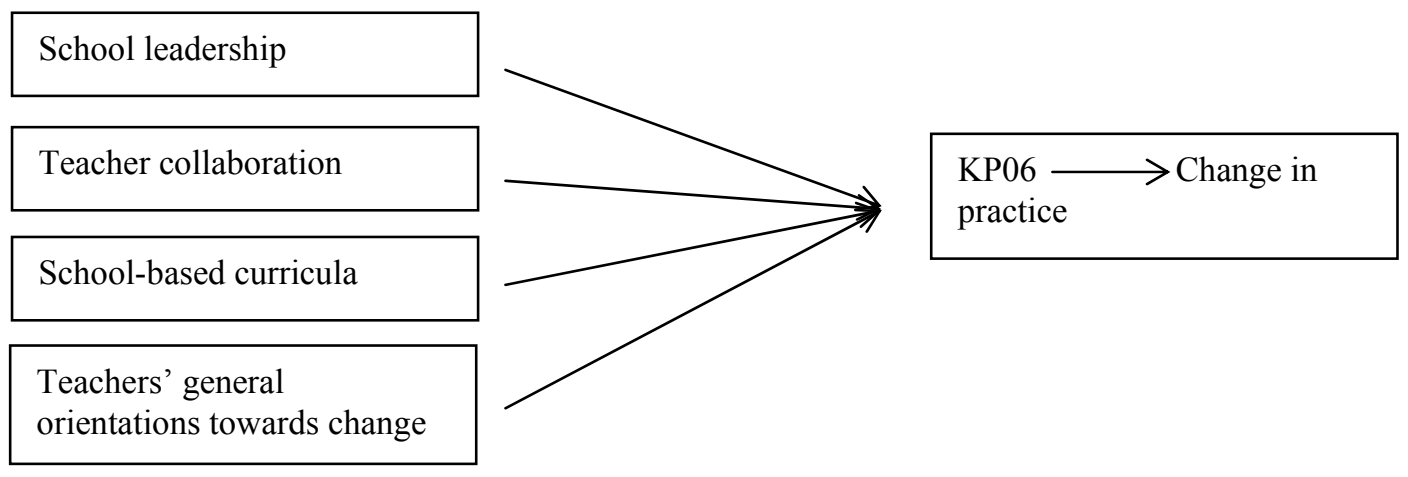

Figure 3. A model of research question (iii) 
Examining these relationships is highly interesting because the history of educational change in Norway resembles the international perspective, through which much has been written about the problem of educational change (e.g., Fullan, 1982; Hargreaves, 2002; Huberman, 1992; Imsen, 2003; Klette, 2003; Sarason, 1971), for instance, teachers' resistance to change (e.g., Cohen, 1998; Cuban, 1993; Elmore, 1996; Tyack \& Cuban, 1995).

Traditionally, studies on educational change have applied qualitative methods, often case studies, to investigate the processes of change (Stoll, 1996). Moreover, teachers' voices have rarely been included in discussions about what changes are needed in education or how to implement initiatives (Hargreaves \& Evans, 1997; Hargreaves \& Shirley, 2011). The latter may be considered a paradox consideringthe ever-increasing pressure on education reform in recent policies that has brought about a renewed focus on the individual teacher as an agent of change in efforts to implement the demands of high standards and improved educational practices (Fullan, 1999; Goodson, 2003; Priestley, 2011; Priestley, Biesta, \& Robinson, 2012). There is also evidence that teachers have often ignored or redefined educational reforms that they perceive as inconsistent with their own perspectives on teaching and schooling (Darling-Hammond, 1990; Fink \& Stoll, 1998; Noregs forskningsråd, 2004; Hargreaves \& Shirley, 2011). With this in mind, an additional aim of the present study is to shed light on teachers' own perspectives on educational change and to contribute knowledge on a topic that has rarely been examined through quantitative analysis.

\section{Theoretical Framework}

\subsection{Agency and Teacher Change}

Theoretical discussions of agency, particularly in sociological studies, focus on how actors are positioned in social contexts and the consequences of their actions (Priestley, Biesta, \& Robinson, 2012). Theories on the concept of agency constitute a broad theoretical framework, including Bourdieu's (1977) notion of habitus and Giddens' (1984) theory of structuration, and a common feature within studies concerning the concept of agency is discussions of the possible relationships between actors and structures, the so-called structure-agency debate. Along these lines, Biesta and Tedder (2007) developed an ecological view of agency that can help to guide research on the interplay between schools, teachers, and educational change. According to the authors, agency is achieved under particular ecological conditions. This notion suggests that the achievement of agency depends on the interaction between the actor's capacities and the contingencies of the environment within which the actions of the actor occur. In this sense, agency is positioned as a relational component that varies according to the social, structural, and material contingencies at the school. Hence, rather than being treated as a capacity within individual teachers, agency becomes construed as an effect of the school conditions through which a teacher's agency is enacted.

Based on the ecological perspective presented by Biesta and Tedder (2007), in the current study, it is argued that the individual capacities of teachers, although important and necessary, are rarely sufficient to effectuate profound and widespread changes in the educational practices of schools and teachers. More specifically, the perspective supports an understanding of teacher agency, i.e., teachers' general orientations towards change, as an emergent capacity intertwined with the characteristics of the school-based conditions of school leadership, teacher collaboration, and the school's development of local curricula. In addition, the perspective allows for understanding the outcome of engaging teachers' agency with school conditions, conceptualised as the degree of perceived reform changes in teachers' teaching. It is, however, in this respect, important to emphasize that teachers' actions are not necessarily determined by the contextual conditions within schools. Teachers may, as reflexive actors, change their classroom practices even if certain conditions appear as obstacles to change (Richardson \& Placier, 2001), or they may exercise "negative" agency by rejecting initiatives of change that they perceive as harmful (Priestley, 2011). Thus, although there are other dynamics of change, as they relate to teacher change, these are not covered in the current study. Other dynamics may, for instance, involve the ways in which teachers position themselves in relation to policies on educational change and the more sophisticated processes through which teachers interact with the social, structural, and material structures within schools and possibly achieve agency within different contexts-for-actions.

\subsection{Important Factors Affecting Educational Change}

Norwegian education authorities have emphasized a number of school-based conditions that are considered crucial in initiating educational change and ensuring that change initiatives are continued beyond the initial implementation phase. As mentioned, the present study covers three of the perhaps most important conditions put forward in the present educational discourse in Norway, namely, school leadership, teacher collaboration, and school-based curriculum development. A brief overview of the policies and research related to these conditions, together with a brief overview of previous research concerning teachers and educational change, as well as 
important features in the National Curriculum Reform for Knowledge Promotion 2006, are provided below.

\subsubsection{Teacher Change}

There are a vast number of studies that have investigated teachers' work and teacher change. Some of these studies have addressed the persistence of teachers who work in a culture of isolation, which serves as a major hurdle in bringing about change and improvement in schools (Little, 1999; Sarason, 1971). Other studies have focused on teacher change in relation to the concept of school culture (e.g., Berg \& Wallin, 1982; Rosenholtz, 1989) and whether and in what ways educational policies and curriculum reforms affect teacher change (e.g., Darling-Hammond, 1990; Fullan \& Hargreaves, 1992; Hopkins, 1990). Furthermore, some studies have focused more directly on how individual teacher characteristics and prior experiences with change initiatives may lead certain teachers to take action and persist in the effort required to successfully implement change initiatives (e.g., Huberman, 1988). Finally, teachers' attitudes have been emphasized as crucial in determining the success or failure of an innovation (Brown \& McIntyre, 1982; Richardson, 1991).

Overall, the legacy of the literature and research on educational change is somewhat ambiguous. Whereas some researchers claim that teachers' practices remain stable and unassailable by external and internal pressures (e.g., Cohen, 1998; Cuban, 1993), other researchers have demonstrated how external change pressures seem to penetrate teachers' practices in more substantial ways (e.g., Coburn, 2004). As noted by Valli and Buese (2007); these apparent contradictions can be explained in part by considering that the indicators of change differ across studies. Stability defeats change in research on external initiatives to change teachers' practices through top-down large-scale reforms, whereas change defeats stability in research on external initiatives to professionalize teaching by making teachers a part of administrative decision-making processes.

In light of the ambiguity embedded in the literature and research on educational change, it is interesting to investigate how Norwegian teachers have managed demands for change and development in their teaching in the wake of the national curriculum reform of 2006. Interestingly, this reform aims to initiate educational change by combining the same strategies that Valli and Buese (2007) used as an analytical distinction to explain the failure or success of previous educational reforms.

\subsubsection{The National Curriculum Reform of 2006 (KP06)}

The National Curriculum Reform for Knowledge Promotion (KP06) consists of the following parts: the core curriculum, the quality framework, distribution of teaching hours per subject, and subject curricula that include competency objectives. The introduction of subject curricula in this form is a new feature with KP06. The previous national curriculum in Norway, National Curriculum for the 10-year Compulsory School 1997, prescribed in detail the content and partly the methods of teaching in terms of process-oriented objectives. The subject curricula in the present KP06curriculum contain few definitions of content and no teaching methods. Thus, unlike the content- and process-oriented previous curriculum of 1997, KP06 is more outcome-oriented because it includes general mandatory competency aims, which means that pupils' learning should be "visible". The latter is followed up through a national quality assessment system, which is emphasized as a regulative tool for the public to hold schools accountable. However, in line with the neo-liberal ideology of decentralized decision-making, it is expected that the local levels, including municipalities, schools, and teachers, will develop their own local curricula that include the proper content and activities for pupils to successfully reach the mandatory competency aims provided in the national curriculum. Furthermore, schools and teachers are expected to include an emphasis on the basic skills to be mastered by each pupil (Note 1), and these skills are to be integrated within competency aims that are consistent with each subject.

Evaluations included in the national programme for evaluating the curriculum reform have addressed several challenges regarding the implementation of the reform. Researchers have, for instance, found traces of what is often referred to as the historical curriculum (Cuban, 1993). By emphasizing teachers as co-constructors of the subject curricula and allowing schools and teachers to determine the proper content and methods, KP06 may lay the grounds for teachers to rely on well-established routines for teaching, thereby hindering educational change (Dale, Engelsen, \& Karseth, 2011). In contrast, a qualitative study conducted by Hodgson et al. (2012) found that competency aims are well integrated in teachers' teaching, whereas integrating the basic skills and strategies of learning appears to be more challenging.

\subsubsection{School-Based Curricula}

A vital aspect of KP06 is the introduction of school-based curricula, in which teachers and school leaders are expected to define the content within the subjects, determine how to organize the teaching, and select working methods and means of assessing pupils' work. Moreover, they are expected to specify the centrally determined 
competency aims into learning objectives and to integrate basic skills into these objectives that are consistent with each subject, as previously mentioned. These learning objectives are to be used to assess pupils' learning achievements during the course of their learning.

The Norwegian education authorities' vision of decentralized decision-making and local freedom in developing the curricula may be viewed in relation to theories of implementation, underpinning how educational change can succeed when those responsible for implementing an initiative are included in discussions regarding the formulations of the initiatives (e.g., Fullan, 2007). Furthermore, the work with school-based curricula may be considered in relation to the notion of implementation quality. Implementation quality emphasizes the importance of ensuring quality in the processes of implementing a given initiative so that the local agents responsible for effectuating change are well informed and well prepared to accomplish the work that is needed to bring about the desired changes (Ertesvåg, 2012). In the case of work with school-based curricula, implementation quality depends on a series of conditions, including the interplay between education authorities, school owners, and school leadership and collaboration between teachers.

Evaluations of work on school-based curricula have shown that schools and teachers experience local freedom and trust in some areas, whereas other areas could be characterized by mechanisms of force and bureaucratizing tendencies. Hence, there seems to be an imbalance between the political and the professional governing of the Norwegian school system (Møller, Prøitz, \& Asen, 2009). Although this imbalance may be interpreted from a range of different perspectives, one explanation centres on the paradox embedded in KP06: local freedom of action is coupled with an expectation of clear steering by management by objectives (MBO) and heightened demands regarding pupils' learning results (Dale et al., 2011).

\subsubsection{School Leadership}

A number of studies have emphasized the importance of school leadership for successful educational change initiatives (e.g., Fullan, 2002; Stoll, 1999). Whereas some studies have focused on the role of the principal (e.g., Louis, 2003), other studies have focused on how leadership may be exercised by several actors within an organization, referred to as, for instance, transformational leadership (e.g., Leithwood \& Jantzi, 2006) or distributed leadership (e.g., Spillane, 2006). Furthermore, in the Norwegian educational discourse, the Official Norwegian Report 2003: 16 In first line-A strengthened primary and secondary education and training states "The principal and school leadership appear as decisive criteria in order to effectuate processes of innovation and educational change" (p. 264).

In a Norwegian study of principals' roles in promoting school development, Midthassel, Bru, and Idse (2000) found that principals can promote development by playing an active role in creating what the researchers call an innovative culture. Moreover, studies have shown that the degree of principals' involvement in and attention to processes of change is decisive for the teachers' degree of commitment and motivation in these processes (e.g., Huberman \& Miles, 1984). Whether principals are involved in the planning and leadership of change initiatives is also important for the quality of implementation (Midthassel \& Ertesvåg, 2008). Finally, McLaughlin and Talbert $(2001,2006)$ found that teachers are in a strategic position to promote collaboration between teachers and that a large proportion of the differences between strong and weak professional communities in sixteen American high-schools could be explained by the role of leadership.

\subsubsection{Teacher Collaboration}

Collaboration between teachers is often treated as a prerequisite for the development of a collective culture, which in turn is treated as a vital factor for the implementation and continuation of change initiatives in schools and in teachers' practices (Ertesvåg, 2012). In the Norwegian educational discourse, collaboration among teachers is emphasized through ideals such as the "school as a learning organisation" (e.g., White Paper no. 31 (2007-2008). Quality in the school) and "professional learning communities" (e.g., White Paper no. 11 (2008-2009). The teacher. The role and the education).

The importance of collaboration between teachers is highlighted in numerous studies. Researchers have claimed that collaboration may bring about new meanings, behaviours, skills, and beliefs regarding the concepts of teaching and learning (e.g., Fullan, 2007); a shared professional language (e.g., Little, 1982); and the development of shared visions and a collective school culture (e.g., McLaughlin \& Talbert, 2001; Rosenholtz, 1989). Moreover, collaboration is considered to be of great importance to the degree of teachers' involvement in the processes of school development (Levine \& Marcus, 2010; McLaughlin, 1993; Vescio, Ross, \& Adams, 2008). Similar findings, although with opposite signs, are emphasized in a Norwegian study of what characterizes schools that have experienced less success in implementing the national curriculum reform KP06. A common feature among schools that have experienced less success is an individualistic learning culture among 
the teachers and thus few arenas for sharing ideas and experiences (Blossing \& Ertesvåg, 2011). Furthermore, in the evaluation of the government programme "Knowledge promotion reform-from word to deed", Blossing, Hagen, Nyen, and Söderström (2010) claimed that Norwegian schools lack professional learning communities that specifically address the improvement of teachers' teaching. School development work tends to concern matters outside of teachers' classroom practices. Finally, in a quantitative survey on time consumption and the organisation of teaching in primary and lower secondary schools in Norway, Strøm, Borge, and Haugsbakken (2009) found that teacher teams have been given responsibility for a number of tasks, including an increased number of administrative tasks. Hence, the teams have been given less time to work on tasks that are most important for their teaching practices or to focus on development work.

\subsubsection{Summary}

Based on the theories and research reviewed above, it is argued that school leadership, teacher collaboration, and school-based curricula make up the social and structural school conditions that may promote or hinder teachers' agency, conceptualized as teachers' general orientations towards change in the current study. In addition, the aforementioned research suggests that these conditions are essential to realizing the National Curriculum Reform of 2006 in teachers' teaching. Possible relationships between these factors are investigated in the next sections through different quantitative analyses of empirical data.

\section{Method}

In order to contribute knowledge on teacher-school relationships and issues of reform-driven changes in teachers' teaching from the perspective of a national probability sample of Norwegian teachers, the current study is based on a survey, i.e., a questionnaire entitled "Teachers' Perspectives on the Development of Practice", developed for the purpose of this investigation. The development of the questionnaire was initiated with nine semi-structured qualitative interviews with teachers from primary and secondary education and training in Norway. The aim of the interview study was to ensure that relevant aspects of change, as perceived by the teachers themselves, were included in the questionnaire. A pilot study was conducted prior to the survey to test and validate the questionnaire. Both the pilot study and the survey were based on an anonymous, paper-based questionnaire.

\subsection{Sample and Implementation}

Participants were Norwegian teachers in public primary and lower secondary schools. To obtain a representative national sample, six counties from four geographic regions in Norway were selected: southern Norway, western Norway, central Norway, and northern Norway. In total, 100 schools were invited to participate, and the number of schools and types of schools (primary, lower secondary and combined schools) in each county were selected by a stratified random procedure in SPSS 20. More specifically, the schools in the sample were randomly selected in proportion to the total number of schools and school types in each county. Altogether, this procedure created 18 strata (six counties and three school types), and the schools within each stratum were selected by weighting the number of teachers in each school. Hence, this procedure secured equal opportunities for teachers to participate in the study.

The sample consists of 52 schools with a total of 738 teachers. The response rate for the schools was $52 \%$, and the response rate at the teacher-level was $50 \%$. Both response rates are considered satisfactory with respect to selectivity (M. Gall, J. Gall, \& Borg, 2007). Moreover, all counties were statistically represented, with the exception of a county in northern Norway, where only one school chose to participate.

The first contact with each school was made by an e-mail sent to the school principal, who was asked whether the school would participate in the survey. The schools that agreed to participate nominated an internal contact person who was in charge of administrating the questionnaire at the school. The questionnaire was distributed by postal mail between May and October 2012.

The sample consists of $75.7 \%$ females and $24.3 \%$ males, fairly identical to the national proportions of female (73.9\%) and male teachers (26.1\%) working in public primary and lower secondary schools. The mean age of the teachers was 44 years. Of the teachers, $64.7 \%$ worked in primary schools $(n=478), 23.9 \%$ in lower secondary schools $(\mathrm{n}=176)$, and $11.4 \%$ in combined schools $(\mathrm{n}=84)$. The school sizes varied from 107 to 636 pupils, with an average of 305 .

\subsection{Instruments}

The questionnaire consisted of 16 scales, including the following 5 scales used in the current study: school leadership, teacher collaboration, school-based curricula, change as a result of the national curriculum reform of 2006 (referred to as Reform changes in the result section and discussion), and teachers' general orientations towards change. All instruments were developed and administered in Norwegian. Hence, sample items represent 
translations from Norwegian to English. Cronbach's alpha was used to assess the measurement reliability of the items for each of the five scales, and alpha coefficients of .70 or higher were considered to be acceptable (Nunnally, 1978). All of the scales yielded satisfactory results concerning the latter threshold. The five scales and sample items are presented below (see Appendix A for details of the items included in the scales).

\subsubsection{School Leadership $(\mathrm{A}=.84)$}

School leadership was measured by a four-item scale. To obtain precise questions and minimise measurement error on the scale, the definition of school leadership was limited to the principal, deputy heads and other agents with formal school leadership responsibilities. The following are examples of these items: "The leadership at this school pays attention to new pedagogical ideas" and "The leadership at this school prioritizes which educational initiatives ought to be implemented". The teachers responded on a six-point Likert scale ranging from "Not at all" (1) to "To a great extent" (6).

\subsubsection{Teacher Collaboration $(\mathrm{A}=.87)$}

This scale measured teachers' perceptions of teacher collaboration within their teams. The scale consisted of four items. The following are sample items: "The teachers engage in informal conversations about different perspectives on teaching (e.g., during breaks)" and "Collaboration between the teachers contributes to new perspectives on teachers' teaching". Responses were provided on a scale ranging from "Not at all" (1) to "To a great extent" (6).

\subsubsection{School-Based Curricula $(\mathrm{A}=.87)$}

This scale consisted of three items measuring the teachers' perceptions of the role of the school-based curricula in their teaching. The following are sample items: "The work of specifying the school-based curricula has been useful for achieving a better understanding of the competency aims" and "The work of specifying the school-based curricula has been useful for achieving a better understanding of the basic skills". The teachers responded on a scale ranging from "To a low degree" (1) to "To a high degree" (6).

\subsubsection{Teachers' General Orientations towards Change $(\mathrm{A}=.75)$}

This scale consisted of four items. The following are sample items: "I frequently initiate teaching projects on my own in order to develop my teaching" and "I am good at implementing new pedagogical ideas in my teaching". The teachers responded on a scale ranging from "Not at all" (1) to "To a great extent" (6).

\subsubsection{Reform Changes $(\mathrm{A}=.83)$}

This scale included five items measuring teachers' perceptions of the degree to which the national curriculum reform of 2006 had brought about changes in their teaching. The following are sample items: "KP06 has made me practice new ways of organizing the pupils in the classroom" and "The competency aims embedded in KP06 are important tools in the planning of my teaching". Responses were provided on a scale ranging from "Strongly disagree" (1) to "Strongly agree" (6).

\subsection{Data Analysis}

Data analyses were conducted using SPSS 20 and AMOS 20. All variables were initially screened for missing scores and checked for outliers and assumptions of normality, i.e., values of skewness and kurtosis. Of the total cases, 173 had to be deleted because the teachers had not taken part in developing school-based curricula. For the remaining 738 respondents, the percentage of missing data for the items included in the study ranged from $0.5 \%$ to $2.6 \%$. Exploratory factor analysis (EFA) was conducted in SPSS to assess the factor structure and validate the questionnaire developed for this study. The EFA yielded a satisfactory structure in that five conditions in accordance with the theoretical framework were extracted (Note 2) (see Table 4 in Appendix B). Furthermore, SPSS was used to produce mean scores, standard deviations, Cronbach's alphas, and correlations between the conditions.

To explore the third research question, the relationships between teachers' perceptions of the school-based conditions, teachers' general orientations towards change, and the degree of perceived reform changes, confirmatory factor analysis (CFA) and structural equation modeling (SEM) were conducted using AMOS 20 software. SEM analysis allows for modeling relationships between multiple predictor and criterion variables as well as investigating both direct and indirect effects between the variables (Hoe, 2008). Furthermore, SEM analysis is considered more effective than multiple regression in parsimonious model testing because the former allows for the investigation of goodness-of-fit indices (Cheng, 2001). Goodness-of-fit indices include assessments of the chi-square statistic $\left(\chi^{2}\right)$, CFI, IFI, TIL, and RMSEA. The chi-square statistic involves considering the $\chi 2$ value relative to its degree of freedom, and a ratio of three or less is indicative of a good fit 
(Kline, 1998). For the CFI, IFI, and TLI, values greater than .90 are considered acceptable and values greater than .95 are considered good fits to empirical data (Byrne, 2010; Hu \& Bentler, 1999). For the RMSEA index, values less than .06 indicate a good fit to data (Hu \& Bentler, 1999). Finally, according to Chin (1998), the standardized regression paths between the scales should be at least .20 to be considered meaningful for discussion.

\section{Results}

\subsection{Descriptive Data and Correlations}

The first research question concerned the extent to which the teachers perceived that the national curriculum reform had resulted in changes in teaching. Table 1 shows the mean scores, middle values and standard deviations for the items included on the reform changes scale. Note that item number 6 is only included in the descriptive analysis; this item was excluded from the summated scale based on the EFA and CFA.

Table 1. Mean scores, middle values and standard deviations for the items included on the Reform changes scale

\begin{tabular}{lll}
\hline Item & $\begin{array}{l}\text { Mean scores (middle } \\
\text { values) }\end{array}$ & $\begin{array}{l}\text { Standard } \\
\text { dev. }\end{array}$ \\
\hline 1. KP06 has made me practice new ways of organizing pupils & $3.44(3.5)$ & 1.19 \\
2. KP06 has made me practice new working methods & $3.58(3.5)$ & 1.16 \\
3. The basic skills have brought about changes in the way I teach & $3.88(3.5)$ & 1.08 \\
4. The competency aims are important tools in the planning of my & $4.65(3.5)$ & 1.09 \\
teaching & $3.29(3.5)$ & 1.26 \\
5. KP06 has altered my attitudes towards education and teaching & $3.80(3.5)$ & 1.11 \\
6. KP06 has brought about new content in my teaching & & \\
\hline
\end{tabular}

The descriptive statistics in Table 1 show that the teachers reported the highest mean score on the competency aims embedded in KP06 as an important tool for planning teaching. The mean scores for the other items were close to the middle value of 3.5 .

The second research question addressed the relationship between teachers' general orientations towards change and the degree of perceived reform changes in teachers' teaching after the national curriculum reform. Table 2 shows the correlations between these two scales and the other scales in the study, together with a selection of demographic variables and statistical means and standard deviations. Mean scores and standard deviations for the scales were computed by adding the values for each item on the different scales and dividing the total by the total number of items included on the scale.

Table 2. Zero-order correlations and descriptive statistics

\begin{tabular}{lllllllll}
\hline Variable & 1 & 2 & 3 & 4 & 5 & 6 & 7 & 8 \\
\hline 1. School leadership & - & & & & & & & \\
2. Teacher collaboration & $.422^{* *}$ & - & & & & & & \\
3. School-based curricula & $.321^{* *}$ & $.179^{* *}$ & - & & & & & \\
4. Teachers' gen. orient. towards change & $.278^{* *}$ & $.247^{* *}$ & $.219^{* *}$ & - & & & & \\
5. Reform changes & $.250^{* *}$ & $.107^{* *}$ & $.302^{* *}$ & $.261^{* *}$ & - & & & \\
6. Sex & .013 & -.021 & $-.119^{* *}$ & $-.099^{* *}$ & $-.132^{* *}$ & - & & \\
7. Age & $.120^{* *}$ & .018 & .053 & -.017 & $.114^{* *}$ & -.072 & - & \\
8. School type & -.052 & -.053 & .003 & -.036 & -.047 & .067 & .027 & - \\
Number of items & 4 & 4 & 3 & 4 & 5 & - & - & - \\
Mean & 4.38 & 5.01 & 4.39 & 4.40 & 3.76 & - & 44.50 & - \\
Standard deviation & 1.10 & 0.89 & 1.16 & 0.91 & 1.16 & - & 11.10 & - \\
\hline
\end{tabular}

** $\mathrm{p}<.01 ; * \mathrm{p}<.05$. Sex: 1. Females, 2. Males. School type: 1. Primary school, 2. Lower secondary school, 3. Combined school. 
Table 2 shows that all of the scales obtained mean scores above the middle value of 3.5 , with the highest score on teacher collaboration (5.01). Interestingly, the scale concerning the degree of perceived reform changes obtained the lowest mean, with a value of 3.76. Furthermore, the zero-order correlations in Table 2 show that the demographic variables were weakly related to the study scales.

Table 3. Correlations between the latent variables in AMOS

\begin{tabular}{llllll}
\hline Latent variable & 1 & 2 & 3 & 4 & 5 \\
\hline 1. School leadership & - & & & \\
2. Teacher collaboration & $.503^{* * *}$ & - & & \\
3. School-based curricula & $.388^{* * *}$ & $.249^{* * *}$ & - & & \\
4. Teachers' gen. orient. towards change & $.348^{* * *}$ & $.306^{* * *}$ & $.281^{* * *}$ & - & \\
5. Reform changes & $.291^{* * *}$ & $.140^{* *}$ & $.356^{* * *}$ & $.331^{* * *}$ & - \\
\hline
\end{tabular}

** $\mathrm{p}<.05 ;{ }^{* * *} p<.001$. Note that the correlations in Table 3 are somewhat stronger than the correlations produced in SPSS shown in Table 2. This result is attributed to the fact that the latent variables in AMOS were free of measurement unreliability effects because measurement errors were captured by the residuals.

The correlations between the scales produced in AMOS in Table 3 varied from weak to moderate, with the strongest correlation between school leadership and teacher collaboration. The correlation between teachers' general orientations towards change and reform changes was moderate. All correlations in Table 3 were significant $(* * \mathrm{p}<.05 ; * * * \mathrm{p}<.001)$. The model measuring correlations between the scales in AMOS showed a good fit to the data $\left(\chi^{2}(158, \mathrm{~N}=738)=385.576 \mathrm{p}<.001, \mathrm{CMIN} / \mathrm{DF}=2.440, \mathrm{RMSEA}=0.044, \mathrm{IFI}=0.966\right.$, TLI $=0.955$, and $\mathrm{CFI}=0.966$ ).

\subsection{SEM Analysis}

The third research question, that concerning the relationships between perceived school-based conditions, teachers' general orientations towards change, and the degree of perceived reform changes in teachers' teaching, was explored by confirmatory factor analysis (CFA) and structural equation modeling (SEM). First, a series of CFAs were conducted to assess the factor structure of the scales. The aim of these analyses was to check the relationships between the observed and latent variables in the models and to assess the fit between the models and the empirical data. All scales showed an acceptable fit to the data considering the previously mentioned thresholds for the goodness-of-fit indices. Because the school-based curricula scale consisted of only three items, no fit indices could be calculated for this scale. For two of the subscales, i.e., school-based curricula and reform changes, covariances between the residuals of two of the items had to be permitted to obtain acceptable fits. Within the two scales, these two pairs of items reflected a highly common meaning owing to the way they were formulated, thereby justifying the covariances.

The hypothesized theoretical model specified school leadership as the independent variable and teacher collaboration, school-based curricula, teachers' general orientations towards change, and reform changes as dependent variables. Based on the previously mentioned theories and research on teachers and educational change, it was expected that school leadership would play a pivotal role in supporting the other four factors included in the study. Furthermore, it was assumed that teacher collaboration would be an important prerequisite for the work with the school-based curricula. In addition, a positive relationship between these two scales and both teachers' general orientations towards change and degree of perceived reform changes was expected. Finally, a positive relationship between teachers' general orientations towards change and reform changes was expected. The hypothesized theoretical model is shown in Figure 4. The model displayed a good fit to the data $\left(\chi^{2}(213, \mathrm{~N}=738)=475.384 \mathrm{p}<.001, \mathrm{CMIN} / \mathrm{DF}=2.232, \mathrm{RMSEA}=0.041, \mathrm{IFI}=0.961, \mathrm{TLI}=0.950\right.$, and $\mathrm{CFI}=$ $0.961)$. 


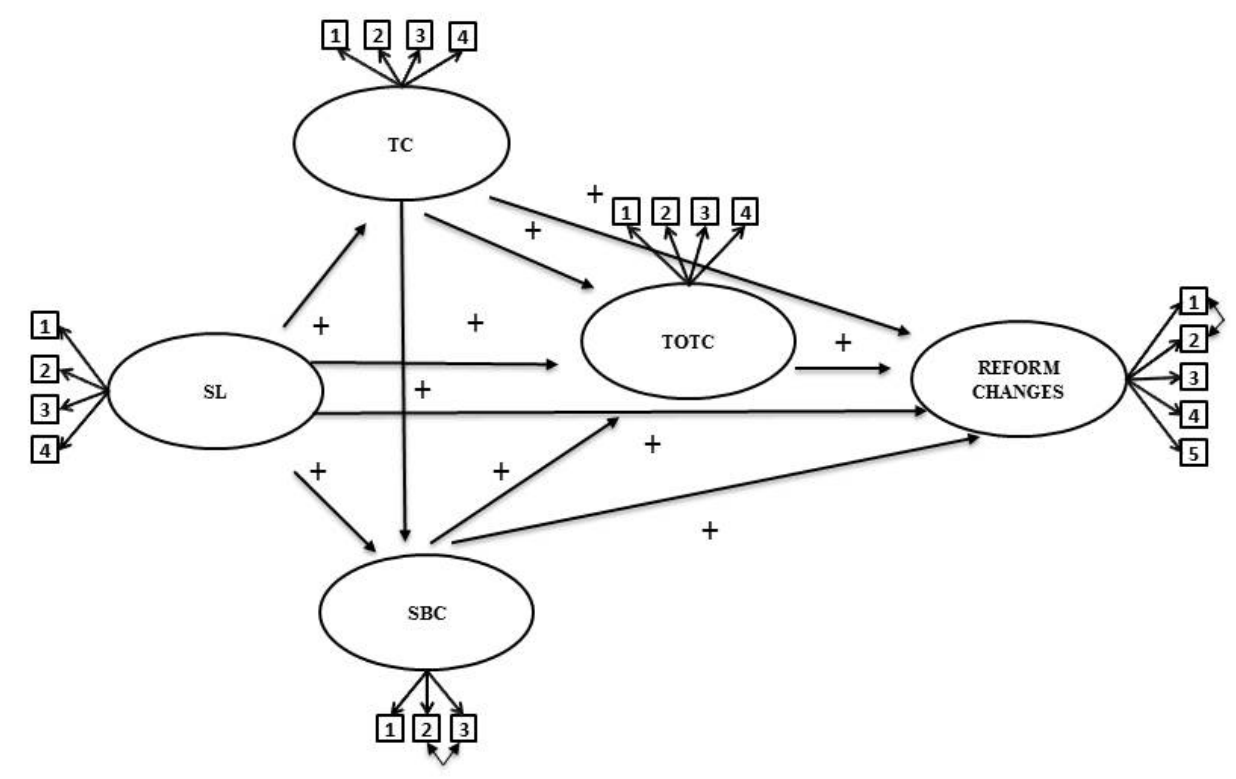

Figure 4. Hypothesized theoretical model of the relationships between school leadership (SL), teacher collaboration (TC), school-based curricula (SBC), teachers' general orientations towards change (TOTC), and perceived changes in teachers' teaching as a result of the national curriculum reform of 2006 (Reform changes)

The results of the analysis of the hypothesized theoretical model (Figure 4) showed no significant standardized regression paths between teacher collaboration and school-based curricula $(.066 ; \mathrm{p}>.05)$; teacher collaboration and reform changes (-.062; $\mathrm{p}>.05)$; or school leadership and reform changes (.054; $\mathrm{p}>.05)$. These non-significant regression weights were removed. The structural model in Figure 5 displayed a good fit to the data $(\chi 2(216, \mathrm{~N}=$ $738)=482.323 \mathrm{p}<.001, \mathrm{CMIN} / \mathrm{DF}=2.233, \mathrm{RMSEA}=0.041, \mathrm{IFI}=0.961, \mathrm{TLI}=0.950$, and $\mathrm{CFI}=0.961)$.

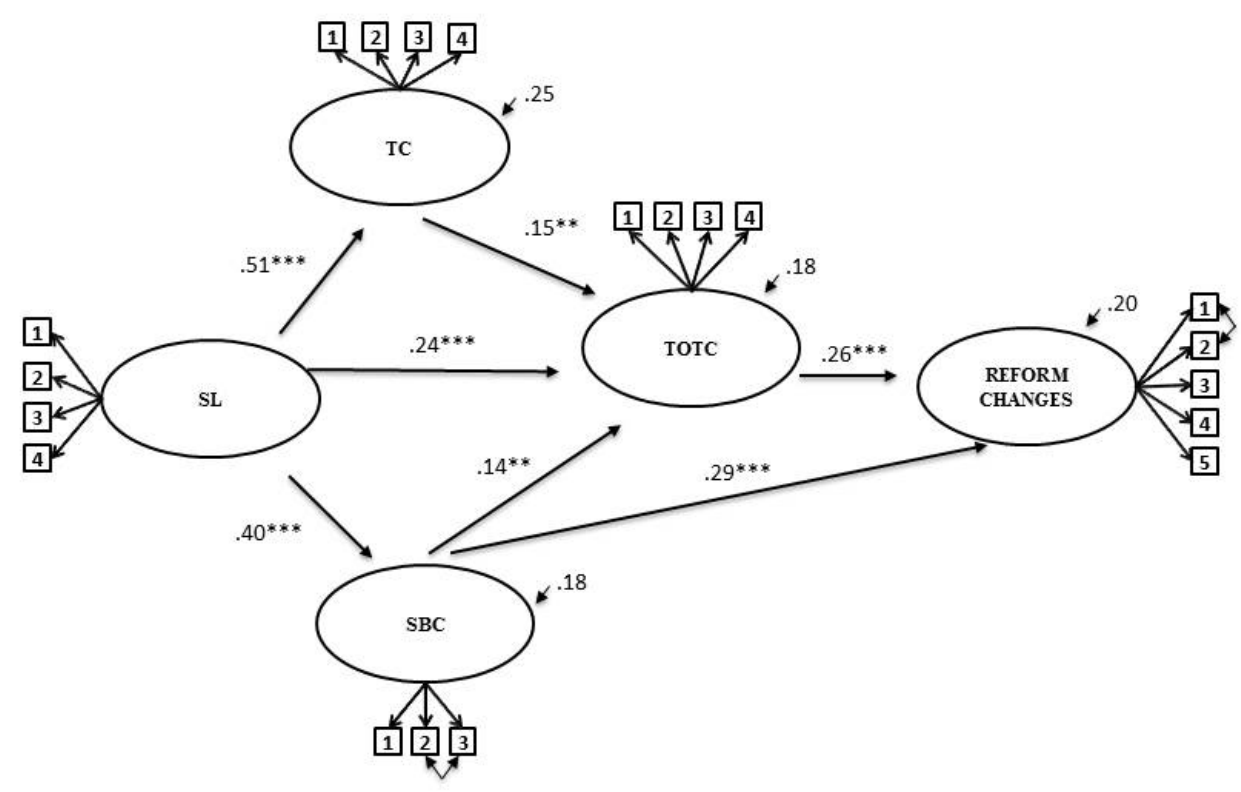

Figure 5. Final structural model of the relationships between school leadership (SL), teacher collaboration (TC), school-based curricula (SBC), teachers' general orientations towards change (TOTC), and perceived changes in teachers' teaching as a result of the national curriculum reform of 2006 (Reform changes). $* * p<.01 ; * * * p$ $<.001$. (See Table 5 in Appendix B for an overview of both direct and indirect standardized effects between the latent variables in Figure 5.) 
The structural model in Figure 5 showed that perceived school organizational conditions, school leadership, teacher collaboration, and school-based curricula accounted for approximately $18 \%$ of the variance in teachers' general orientations towards change, with the strongest direct effect from school leadership $(.24 ; \mathrm{p}<.001)$. The relationships between the scales that constituted school conditions showed moderate to strong relationships between school leadership and teacher collaboration $(.50 ; \mathrm{p}<.001)$ and school leadership and school-based curricula $(.40 ; \mathrm{p}<.001)$. Furthermore, the model showed that only teachers' general orientations towards change and school-based curricula were directly related to reform changes. These two scales accounted for approximately $20 \%$ of the variance in reform changes. School leadership and teacher collaboration were indirectly related to reform changes, mediated through teachers' general orientations towards change. The weak effects of teacher collaboration and school-based curricula on teachers' general orientations towards change were somewhat unexpected (.15; $\mathrm{p}<.005$ and $.14 ; \mathrm{p}<.005$, respectively).

\section{Discussion}

The purpose of this study was to explore the relationships between teachers' perceptions of important school-based conditions for effectuating change, their general orientations towards change, and the degree of perceived changes in their teaching as a result of the latest national curriculum reform in Norway, which commenced in 2006. The study investigated three research questions by means of descriptive data, correlations and SEM analysis.

(i) The first research question concerned the extent to which Norwegian teachers perceived that the national curriculum reform had resulted in changes in the ways they taught. The mean values in Table 1 show some variation between the items included on the reform changes scale. The values indicate, for instance, that the national curriculum reform to a moderate extent changed the ways in which Norwegian teachers organized their pupils and how they practiced new working methods in the classroom, with values close to the middle (3.5) on the Likert scale. The item regarding the degree to which the reform had brought about new content in teachers' teaching obtained a slightly higher mean value of 3.80. Although the standard deviations of the three items indicate moderate dispersion around the mean value $(1.19,1.16$, and 1.11) the obtained mean values of the three items taken together indicate that the freedom of choice regarding methods and content, handed over to the teachers by the education authorities, resulted in changes in teachers' teaching only to a modest degree. This result is in accordance with the findings of Dale et al. (2011) indicating that the freedom of choice and the different possible interpretations embedded in KP06 may lead teachers to adjust KP06 to established practices, resulting in a moderate degree of educational change.

The item regarding the degree to which the basic skills had resulted in changes obtained a mean value of 3.88 . This value can be interpreted as moderate, considering the education authorities' strong emphasis on the integration of such skills in the subject curricula and in teaching. The standard deviation of 1.08 indicates moderate variations among teachers' responses, in accordance with the evaluation conducted by Hodgson et al. (2012).

In contrast, the results in Table 1 indicate that the competency aims were rather important for the planning of teachers' teaching, with a mean value of 4.65. This result is in line with the findings of the qualitative study conducted by Hodgson et al. (2012), as explained previously. A possible explanation for the importance of the competency aims is the central position of these aims in the national quality assessment system. The introduction of KP06 was followed by an increased focus on the assessment of pupils' learning, which is assessed by the pupils' attainment of the competency aims. Hence, the close link between pupils' attainment of the aims and the increased focus on assessment, including, for example, national tests, might provide for the centrality of the competency aims in teachers' practices. Another explanation of the importance of the aims is that they have clarified what is expected of teachers and pupils in the teaching process. A recent study has suggested that Norwegian teachers have positive attitudes towards the competency aims because they clearly illustrate what each pupil must work on to make progress in learning (Ramberg, in press). Note that the standard deviation of the item regarding the competency aims was moderate at 1.09. A possible explanation for this moderate value is that the study encompassed teachers from all four major parts of Norway, thus including both large and small municipalities with regard to number of inhabitants. The municipalities, as school owners, have been given greater responsibility for the quality of schools, including specifying the centrally provided competency aims in the subject curricula. Therefore, the teachers in the current study may have perceived the importance of the aims somewhat differently depending on the degree to which the municipality and the local school possessed the competencies needed to accomplish, arrange for, and prioritize the work. Further research should be carried out to examine such possible multilevel relationships. 
(ii) The second research question concerned the relationship between teachers' general orientations towards change and the degree of perceived reform changes in their teaching. The result of the correlation analysis in AMOS (Table 3) showed a moderate positive correlation between the two scales, $\mathrm{p}<.001(\mathrm{r}=.331)$. The correlation underlines the importance of strengthening teachers' orientations and skills towards school development work, for example, by emphasizing continuing education and training for teachers. Moreover, the positive relationship supports the education authorities' emphasis on teachers as key agents of change. However, it is important to note that the correlation analysis does not necessarily imply a causal relationship. The result might be interpreted in the opposite direction as well; that the teachers may have considered themselves change-oriented because they had implemented components of the latest national curriculum reform in their teaching. A third possible explanation of the relationship is to consider it a result of the continuous processes of interactions between the two scales, a reciprocal causal relationship.

(iii) The third research question focused on the relationships between the perceived school organizational conditions, teachers' general orientations towards change, and the degree of perceived reform changes in teachers' teaching. The results obtained from the analyses of the SEM models (Figure 4 and Figure 5) are in accordance with those of previous research that suggested positive relationships between school leadership and teachers' degree of involvement in development work (e.g., Midthassel et al., 2000); teacher collaboration and development work (e.g., Fullan, 2007); and education authorities' expectations of reinforcing the teacher as an agent for developing their own teaching through their work with school-based curricula. Furthermore, as expected from the theoretical framework, the SEM models showed a positive direct relationship between school-based curricula and reform changes. The positive direct relationship between teachers' general orientations towards change and the degree of perceived reform changes was also in accordance with theories on teachers and educational change. However, the theoretical model in Figure 4 showed no significant regression paths between teacher collaboration and school-based curricula, teacher collaboration and reform changes, or school leadership and reform changes. School leadership and teacher collaboration were indirectly related to reform changes, mediated through teachers' general orientations towards change. A possible explanation for the indirect relationship between school leadership and reform changes is that a school's leadership can primarily support teachers by providing them with the structures and resources needed to implement curriculum reform; however, whether a teacher carries out changes in classroom practice is the teacher's private decision. The indirect relationship may indicate that teachers remain in charge of their teaching, despite the introduction of neo-liberal instruments such as assessment systems and control systems to improve their work. Furthermore, the non-significant relationship between school-based curricula and teacher collaboration was somewhat unexpected considering the theoretical and education policy perspectives on collaboration between teachers as important for successfully developing local curricula. Together with the aforementioned non-significant path between teacher collaboration and reform changes, this finding may indicate that teacher collaboration is rather unfruitful with respect to work with local curricula and to bringing about changes in teachers' teaching. I will further address issues concerning teacher collaboration in the discussion of the structural model below.

The analysis of the structural model (Figure 5) revealed several interesting relationships between the scales in the study. In accordance with the correlation analysis in Table 3, the model results indicated relatively strong direct relationships between school leadership and teacher collaboration (.51) and school-based curricula (.40). These findings suggest that the educational authorities' emphasis on the role of school leadership in promoting these two components (e.g., NOU, 2003; White Paper no. 31 (2007-2008)) has been successful. The direct relationship between school leadership and teachers' general orientations towards change was somewhat weaker, with a coefficient of .24. Nevertheless, the regression path indicates that an increased focus on pedagogical ideas and initiatives from leadership had a positive effect on teachers' general orientations towards change. Hence, the path suggests that the ways in which leadership arrange for and support school development work have consequences for teachers' capacity to promote educational change.

Despite the relatively strong relationships between school leadership and school-based curricula and teacher collaboration, the structural model showed that the two latter scales were weakly related to teachers' general orientations towards change (.14 and .15). A possible explanation for the weak relationship between teacher collaboration and teachers' general orientations towards change is that the collaborative work only involved discussions regarding school development to a limited extent. This explanation is in line with previous research suggesting that the work of Norwegian teachers in professional learning communities does not necessarily include discussions regarding how to improve teachers' teaching (Blossing et al., 2010). Rather, teamwork among teachers may include discussions regarding the administrative conditions for teachers' work, e.g., discussions regarding time spent on teaching and the organization of teaching rather than discussions on 
development work (Strøm et al., 2009). However, the teachers seemed to be very satisfied with the collaboration at their schools: this scale obtained a mean value of 5.01 in this study (Table 2). Taken together, these results are highly interesting, and future research should explore the nature of collaboration in teachers' work more closely.

A possible explanation for the weak relationship between school-based curricula and teachers' general orientations towards change is that the work with local subject curricula constitutes only a minor part of teachers' perspectives on teaching and development. Moreover, the three scales that composed perceived school-based conditions accounted for only $18 \%$ of the variance in teachers' general orientations towards change, implying that caution must be emphasized because the structural model was limited in regard to the amount of variance explained. School leadership accounted for approximately $25 \%$ of the variance in the teacher collaboration scale and $18 \%$ of the variance in school-based curricula. Hence, although the regression weights in the structural model illustrated tendencies regarding the relationships between the scales, a large proportion of the variation in teachers' responses was not accounted for in the current study.

The structural model in Figure 5 showed that only school-based curricula and teachers' general orientations towards change were directly related to reform changes (.29 and .26 , respectively). The positive relationship between local curricula and reform changes may be interpreted in accordance with the notion of implementation quality (Ertesvåg, 2012). There is reason to believe that the quality of the work with local curricula, e.g., whereby teachers in collaboration with other actors within the school system discuss how to interpret the various elements in the curriculum, is positively related to the degree of perceived reform changes in teachers' teaching. Furthermore, the positive relationship can be viewed in light of theories of implementation, which have underlined the importance of teachers' feeling a sense of "ownership" when implementing change initiatives. This perspective supports an understanding of why teachers who had engaged in professional discussions regarding the role of curricula in their teaching may have perceived that KP06 had led to a higher degree of changes in their teaching.

The positive relationship between teachers' general orientations towards change and reform changes can be interpreted in light of theories of agency, i.e., how orientations towards change are directly related to the degree of perceived reform changes in teaching. Such a perspective focuses on how the degree of reform changes in teachers' teaching is a result of the degree of teachers' agency. However, the relatively low amount of variance on the reform changes scale explained by teachers' general orientations towards change and school-based curricula $(20 \%)$ requires caution. Future research should consider including additional constructs and explore relationships between teachers' agency and educational change by means of longitudinal studies.

The overall positive relationships between the scales in the structural model can be viewed in relation to the ecological perspective of Biesta and Tedder (2007), in which teachers' agency is closely related to the social and structural conditions at a given school. The structural model showed that the school-based conditions of school leadership, teacher collaboration and school-based curricula were positively related to teachers' general orientations towards change and that the latter were also directly related to reform changes. The results thus emphasize the need to work systematically to further strengthen relevant support systems to assist teachers in implementing curriculum reforms and other change initiatives. Furthermore, considering the weak relationship between teacher collaboration and teachers' general orientations towards change and the non-significant path between teacher collaboration and reform changes, this study calls for further research that explores the nature of collaboration between teachers and the quality of the collaborative ways of working with regard to discussions of school development work.

\section{Conclusion}

The findings of this study suggested that the overall influence of the reform on teachers' teaching was moderate, with the exception of the competency aims embedded in the curriculum reform that were perceived to be rather important for teachers' teaching. The results also suggested that teachers' general orientations towards change were positively related to the degree of perceived reform changes in their teaching. This study thus underscores the importance of supporting teachers as agents of change in efforts to reform and improve educational practices.

Although the results of the SEM-models indicated that the school-based conditions of school leadership and teacher collaboration exert little direct influence on teachers' perceptions of reform changes, perhaps reflecting the broader notion of the isolated teacher who closes the classroom door to external pressures (Lortie, 1975), the results emphasize that these conditions nevertheless play a crucial role in teachers' efforts to bring about change. For instance, the important work of school leadership in promoting favourable school conditions for teachers' change of practices is particularly apparent in the current study. However, considering that the school-based curricula work exerted a direct influence on teachers' perceived reform changes and thus seemed to have had a 
greater impact on teacher change, the findings of this study illuminate the need for schools to continuously consider how organizational conditions may serve to support and develop issues of teacher change and curriculum implementation more successfully.

\section{Limitations and Suggestions for Future Research}

The results of this study should be considered in light of some limitations. First, it should be emphasized that the use of self-reporting data as a unique source for information may involve potential biases. There is no control over the congruence between the ways in which teachers perceive reform changes and the extent to which they actually carry out changes in their teaching. Although some studies have shown that there may exist a gap between reported changes and actual behaviour in schools (e.g., Meirink, Meijer, \& Verloop, 2007), other studies have reported that there is often good agreement between teacher self-report and observations or teacher logs (e.g., Mayer, 1999). Second, a cautionary concern regarding the interpretation of causality in the SEM analyses must be mentioned. Although the SEM models were causal in nature, the cross-sectional design of the study precluded causal analysis and inferences. The directions of the regression paths were based on theories of educational change and the Norwegian education authorities' emphasis on school leadership, collaboration between teachers, and school-based curricula as vital conditions for promoting change and improved educational practices. However, it can be argued that the relationship can operate in the opposite direction, i.e., that teachers' general orientations towards change influence school organizational conditions. Moreover, the relationship may have emerged as a result of reciprocal causal interactions. Because the study was based on a cross-sectional design that only represented a snapshot of educational reforms and teacher change, longitudinal studies are needed to achieve thorough understanding of change efforts and the sustainability of change initiatives and to explore notions of causality.

Considering the possible reciprocal relationships between school conditions and teachers' general orientations towards change, future research should also explore interactions between these two constructs and the possible ways in which teachers' agency influences such interactions. In this sense, a combination of qualitative and quantitative data may be fruitful. Such studies would extend the literature and research on educational change because there is a gap in our understanding of change at the interface between individual teachers and their schools (Richardson \& Placier, 2001). Moreover, in-depth qualitative studies are called upon to more fully understand the concept of teacher agency as a situated achievement. Emirbayer and Mische (1998), for instance, argued for a conception of agency that encompasses the interplay between an actor's influences from the past, orientations towards the future and engagement with the present. In this sense, the achievement of agency depends on teachers' past professional experiences, teachers' orientations towards the future, e.g., in terms of objectives and values, and teachers' decision making and actions in interactions with their daily working environments. Future studies on teachers and educational change should consider pursuing notions of agency more thoroughly.

Finally, the SEM models included in this study present a simplified impression of reality, meaning that they are limited with regard to the complexities embedded in the relationships between teachers and educational change. Hence, future research should include additional conditions from different levels within the school system; however, in developing more advanced models, researchers must bear in mind that measurement becomes increasingly difficult in proportion to the number of levels and variables included.

\section{References}

Berg, G., \& Wallin, E. (1982). Organisationsutveckling $i$ skolan eller utveckling av skolan som organisation [Organisational development in schools or development of schools as organisations; in Swedish]. Lund: Studentlitteratur.

Biesta, G., \& Tedder, M. (2007). Agency and learning in the lifecourse: Towards an ecological perspective. Studies in the Education of Adults, 39, 132-149.

Blossing, U., \& Ertesvåg, S. K. (2011). An individual learning belief and its impact on schools' improvement work-An Individual versus a Social Learning Perspective. Education Inquiry, 2(1), 153-171.

Blossing, U., Hagen, A., Nyen, T., \& Söderström, A. (2010). «Kunnskapsløftet - fra ord til handling» Sluttrapport fra evalueringen av et statlig program for skoleutvikling [«Knowledge promotion reform-from word to deed» A final report from the evaluation of a government programme for school development; in Norwegian] Fafo.

Bourdieu, P. (1977). Outline of a theory of practice. Cambridge, UK: Cambridge University Press. http://dx.doi.org/10.1017/CBO9780511812507 
Brown, S., \& McIntyre, D. (1982). Infuences upon teachers' attitudes to different types of innovation: a study of Scottish Integrated Science. Curriculum Inquiry, 12(1), 35-51. http://dx.doi.org/10.2307/1179745

Byrne, B. M. (2010). Structural equation modeling with AMOS: Basic concepts, applications, and programming. New York: Routledge.

Cheng, E. W. L. (2001). SEM being more effective than multiple regression in parsimonious model testing for management development research. Journal of Management Development, 20(7), 650-667. http://dx.doi.org/10.1108/02621710110400564

Chin, W. W. (1998). Issues and opinion on structural equation modeling. MIS Quarterly, 22(1), 7-16.

Coburn, C. E. (2004). Beyond decoupling: Rethinking the relationship between the institutional environment and the classroom. Sociology of Education, 77(3), 211-244. http://dx.doi.org/10.1177/003804070407700302

Cohen, D. K. (1988). Teaching Practice: Plus Que ca Change ... . In P. Jackson (Ed.), Contributions to Educational Change: Perspectives on Research and Practice (pp. 27-84). Berkeley, CA: McCutcheon.

Cuban, L. (1993). How teachers taught: Constancy and change in American classrooms, 1890-1990 (2nd ed.). New York: Teachers College Press.

Dale, E. L., Engelsen, B. U., \& Karseth, B. (2011). Kunnskapsløftets intensjoner, forutsetninger og operasjonaliseringer: En analyse av en leereplanreform. Sluttrapport [The intensions, premises and formulations of the Knowledge Promotion Reform 2006. An analysis of a national curriculum reform. Final report; in Norwegian]. UIO: PFI.

Darling-Hammond, L. (1990). Instructional Policy Into Practice: The Power of the Bottom Over the Top. Educational Evaluation and Policy Analysis, 12(7), 339-347.

Elmore, R. F. (1996). Getting to scale with good educational practice. Harvard Educational Review, 66(1), 1-26.

Emirbayer, M., \& Mische, A. (1998). What is agency? American Journal of Sociology, 103(4), 962-1023. http://dx.doi.org/10.1086/231294

Enders, C. K. (2001). A Primer on Maximum Likelihood Algorithms Available for Use With Missing Data. $\begin{array}{lllll}\text { Structural Equation Modeling: A Multidisciplinary journal, } & 8(1), & 128-141 .\end{array}$ http://dx.doi.org/10.1207/S15328007SEM0801_7

Ertesvåg, S. K. (2012). Leiing av endringsarbeid i skulen [The management of development work in the school; in Norwegian]. Oslo: Gyldendal Norsk Forlag AS.

Fink, D. (1992). Invitational leadership. In J. Novak (Ed.), Advances in invitational theory. San Francisco: Caddo Gap Press.

Fink, D., \& Stoll, L. (1998). Educational Change: Easier Said than Done. In A. Hargreaves, A. Lieberman, M. Fullan, \& D. W. Hopkins (Eds.), International Handbook of Educational Change. Great Britain: Kluwer Academic Publishers.

Fullan, M. (1982). The meaning of educational change. New York: Teachers College Press.

Fullan, M. (1991). The new meaning of educational change. London: Cassell.

Fullan, M. (1993). Change forces: Probing the depths of educational reform. London: Falmer Press.

Fullan, M. (1999). Change forces : The sequel. London: Falmer.

Fullan, M. (2002). The role of leadership in the promotion of knowledge. Teachers and Teaching: Theory and practice, 8(3/4), 409-419. http://dx.doi.org/10.1080/135406002100000530

Fullan, M. (2007). The new meaning of educational change. London: Routledge.

Fullan, M., \& Hargreaves, A. (1992). Teacher development and educational change. London: Falmer Press.

Gall, M. D., Gall, J. P., \& Borg, W. R. (2007). Educational research: An introduction (8th ed.). Boston: Allyn and Bacon.

Giddens, A. (1984). The constitution of society: Outline of the theory of structuration. Cambridge, UK: Polity.

Goodlad, J. I. (1984). A place called school: Prospects for the future. New York: McGraw-Hill.

Goodson, I. (2003). Professional knowledge, professional lives. Maidenhead: Open University Press.

Hargreaves, A. (2002). Sustainability of educational change: The role of social geographies. Journal of Educational Change, 3(3-4), 189-214. http://dx.doi.org/10.1023/A:1021218711015 
Hargreaves, A., \& Evans, R. E. (1997). Beyond Educational Reform: Bringing Teachers Back In. Buckingham: Open University Press

Hargreaves, A., \& Shirley, D. (2011). The far side of educational reform. Ottawa, Ontario: Canadian Teachers' Federation.

Hargreaves, D. H. (1995). School culture, school effectiveness and school improvement. School Effectiveness and School Improvement, 6(1), 23-46. http://dx.doi.org/10.1080/0924345950060102

Hodgson, J., Rønning, W., \& Tomlinson, P. (2012). Sammenhengen Mellom Undervisning og Laring. En studie av loereres praksis og deres tenkning under Kunnskapsløftet. Sluttrapport (Vol. 4) [The SMUL-project, the relationship between teaching and learning. Ways of working, development of skills and learning in Norwegian, science and social studies. Final report; in Norwegian]. Bodø: Nordlandsforskning.

Hoe, S. L. (2008). Issues and procedures in adopting structural equation modeling technique. Journal of Applied Quantitative Methods, 3, 76-83.

Hopkins, D. (1990). Integrating staff development and school improvement: A study of teacher personality and school climate. In B. Joyce (Ed.), Changing school culture through staff development, 1990 Yearbook of Association for Supervision and Curriculum Development (pp. 41-68). Alexandria, VA: Association for Supervision and Curriculum Development.

Hopkins, D., Ainscow, M., \& West, M. (1994). School improvement in an era of change. London: Cassell.

Hu, L. T., \& Bentler, P. M. (1999). Cutoff criteria for fit indexes in covariance structural analysis: Conventional criteria versus new alternatives. Structural Equation Modeling: A Multidisciplinary journal, 6(1), 1-55. http://dx.doi.org/10.1080/10705519909540118

Huberman, M. (1988). Teacher careers and school improvement. Journal of Curriculum Studies, 20(2), 119-132. http://dx.doi.org/10.1080/0022027880200202

Huberman, M. (1992). Teacher development and instructional mastery. In A. Hargreaves, \& M. G. Fullan (Eds.), Understanding teacher development (pp. 122-142). New York: Teachers College Press.

Huberman, M., \& Miles, M. B. (1984). Innovation up close: How school improvement works. New York: Plenum Press. http://dx.doi.org/10.1007/978-1-4899-0390-7

Imsen, G. (2003). Skolemiljø, loeringsmiljø og elevutbyttelen empirisk studie av grunnskolens 4., 7. og 10. Trinn [School environment, learning environment and student outcomes: An empirical study of 4th, 7th and 10th grade in primary and lower secondary education; in Norwegian]. Trondheim: Tapir akademisk forlag.

Klette, K. (2003). Klasserommets praksisformer etter Reform 97 Evaluering av Reform 97. Rapport no. 1. [Classroom practices after Reform 97 Evaluations of Reform 97 Report no. 1; in Norwegian]. Oslo: Unipub AS.

Kline, R. B. (1998). Principles And Practice Of Structural Equation Modeling. New York: Guilford Press.

Kunnskapsløftet. Læreplan for grunnskolen og videregående opplæring. (2006). [The Knowledge Promotion Reform. Education reform 2006 in primary, lower secondary and upper secondary education and training]. Oslo: Nasjonalt læremiddelsenter

Læreplanverket for den 10-årige grunnskolen. (1996). [The National Curriculum for the 10-year Compulsory School 1997]. KUF. Oslo: Nasjonalt læremiddelsenter.

Leithwood, K., \& Jantzi, D. (2006). Transformational school leadership for large-scale reform: Effects on students, teachers, and their classroom practices. School Effectiveness and School Improvement, 17(2), 201-227. http://dx.doi.org/10.1080/09243450600565829

Levine, T. H., \& Marcus, A. S. (2010). How the structure and focus of teachers' collaborative activities facilitate and constrain teacher learning. Teaching and Teacher Education, 26(3), 389-398. http://dx.doi.org/10.1016/j.tate.2009.03.001

Little, J. W. (1982). Norms of Collegiality and Experimentation: Workplace Conditions of School Success. American Educational Research Journal, 19(3), 325-340. http://dx.doi.org/10.3102/00028312019003325

Little, J. W. (1990). The Persistence of Privacy: Autonomy and Initiative in Teachers' Professional Relations. Teachers College Record, 91(4), 509-536.

Little, J. W. (1999). Organizing Schools for Teacher Learning. In L. Darling-Hammond, \& G. Sykes (Eds.), Teaching as the Learning Profession: Handbook of Policy and Practice (pp. 233-262). San Francisco: 
Jossey-Bass.

Lortie, D. C. (1975). Schoolteacher: A sociological study. Chicago: The University of Chicago Press.

Louis, K. S. (2003). School Leaders Facing Real Change: Shifting geography, uncertain paths. Cambridge Journal of Education, 33(3), 371-382. http://dx.doi.org/10.1080/030576403200012208

Louis, K. S., \& Miles, M. B. (1990). Improving the urban high school: The what and how. New York: Teachers College Press.

Mayer, D. (1999). Measuring instructional practice: Can policymakers trust survey data? Educational Evaluation and Policy Analysis, 21(1), 29-45. http://dx.doi.org/10.3102/01623737021001029

McLaughlin, M. W. (1993). What Matters Most in Teachers' Workplace Context? In J. W. Little, \& M. W. McLaughlin (Eds.), Teachers' Work. Individuals, Colleagues, and Contexts (pp. 79-103). New York: Teachers College Press.

McLaughlin, M., \& Talbert, J. (2001). Professional communities and the work of high school teaching. Chicago: University of Chicago Press.

McLaughlin, M., \& Talbert, J. (2006). Building school-based teacher learning communities. New York: Teachers College Press.

Meirink, J., Meijer, P. C., \& Verloop, N. (2007). A closer look at teachers' individual learning in collaborative settings. Teachers and Teaching: Theory and practice, 13(2), 145-164. http://dx.doi.org/10.1080/13540600601152496

Midthassel, U. V., \& Ertesvåg, S. (2008). Schools implementing Zero. The process of implementation an anti bullying programme in six Norwegian schools. Journal of Educational Change, 9(2), 53-172. http://dx.doi.org/10.1007/s10833-007-9053-7

Midthassel, U. V., Bru, E., \& Idse, T. (2000). The Principal's Role in Promoting School Development Activity in Norwegian Compulsory Schools. School Leadership \& Management: Formerly School Organisation, 20(2), 247-260. http://dx.doi.org/10.1080/13632430050011461

Møller, J., Prøitz, T., \& Aasen, P. (2009). Samspillet mellom styrings-og forvaltningsnivåene [The interplay between levels of steering and management]. In J. Møller, T. Prøitz, \& P. Aasen (Eds.), Kunnskapsløftet-tung bør å bore? Underveisanalyse av styringsreformen i skjaringspunktet mellom politikk, administrasjon og profesjon (Vol. 42, pp. 177-184) [The Knowledge Promotion 2006: A heavy burden? A temporary analysis of the reform in the point of intersection between politics, administration and profession; in Norwegian]. NIFU STEP.

Mortimore, P. (1998). The Vital Hours: Reflecting on Research on Schools and their Effects. In A. Hargreaves et al. (Eds.), International Handbook of Educational Change (pp. 85-99). Dordrecht: Kluwer Academic Publishers.

Noregs forskningsråd. (2004). Resultat frå evalueringa av Reform 97 [The evaluation of Reform 97; in Norwegian]. Retrieved from http://www.forskningsradet.no

NOU. (2003). 2003:16 I første rekke. Forsterket kvalitet $i$ en grunnopplaring for alle [Official Norwegian Report 2003:16 In first line-A strenghtened primary and secondary eduaction and training]. Oslo: UFD.

Nunnally, J. O. (1978). Psychometric theory. New York: McGraw-Hill.

Priestley, M. (2011). Schools, teachers, and curriculum change: A balancing act? Journal of Educational Change, 12(1), 1-23. http://dx.doi.org/10.1007/s10833-010-9140-z

Priestley, M., Biesta, G., \& Robinson, S. (2012). Teachers as agents of change: An exploration of the concept of teacher agency. Working paper no. 1, Teacher Agency and Curriculum Change. In S. o. Education (Ed.). University of Sterling.

Ramberg, M. R. (2013). Teacher Change in an Era of Neo-liberal Policies-A neo-institutional analysis of teachers'perceptions of their professional change [In press].

Richardson, V. (1991). How and why teachers change. In S. C. Conley, \& B. S. Cooper (Eds.), The School as a Work Environment: Implications for Reform (pp. 66-87). Boston, MA: Allyn and Bacon.

Richardson, V., \& Placier, P. (2001). Teacher Change. In V. Richardson (Ed.), Handbook of research on teaching (pp. 905-947). Washington, DC: American Educational Research Association. 
Rosenholtz, S. J. (1989). Teachers' workplace: The social organization of schools. New York: Longman.Rutter, M. (1983). School effects on pupil progress: Research findings and policy implications. In L. Shulman, \& G. Sykes (Eds.), Handbook of Teaching and Policy (pp. 3-41). New York: Longman.

Sarason, S. B. (1971). The culture of the school and the problem of change. Boston: Allyn \& Bacon.

Sarason, S. B. (1990). The predictable failure of educational reform: Can we change course before it's too late? San Francisco: Jossey-Bass.

Spillane, J. P. (2006). Distributed leadership. San Francisco, Cal.: Jossey-Bass.

St.meld. nr. 11. (2008-2008). Laereren. Rollen og utdanningen [White Paper no. 31 The teacher. The role and the education]. Oslo: KD.

St.meld. nr. 30. (2003-2004). Kultur for laering [White Paper no. 30 Culture for learning]. Oslo: UFD.

St.meld. nr. 31. (2007-2008). Kvalitet i skolen [White Paper no. 31 Quality in the school]. Oslo: KD.

Stoll, L. (1996). Linking school effectiveness and school improvement: issues and possibilities. In J. Gray, D. Reynolds, C. Fitz-Gibbon, \& D. Jesson (Eds.), Merging Traditions: The future of research on school effectiveness and school improvement. London: Cassell.

Stoll, L. (1999). Realising our potential: Understanding and developing capacity for lasting improvement. School Effectiveness and School Improvement, 10(4), 503-532. http://dx.doi.org/10.1076/sesi.10.4.503.3494

Strøm, B., Borge, L. E., \& Haugsbakken, H. (2009). Tidsbruk og organisering i grunnskolen: Sluttrapport (Vol. 4): SØF [The use of time and organization in primary and lower secondary school. Final report; in Norwegian].

Teddlie, C., \& Stringfield, S. (1993). Schools make a difference. New York: Teachers College Press.

Teddlie, C., Kirby, P., \& Stringfield, S. (1989). Effective vs. ineffective schools: Observable differences in the classroom. American Journal of Education, 97(3), 221-236. http://dx.doi.org/10.1086/443925

Tyack, D., \& Cuban, L. (1995). Tinkering Toward Utopia: A Century of School Reform. Cambridge, MA: Harvard University Press.

Tyack, D., \& Tobin, W. (1994). The Grammar of Schooling-Why Has It Been So Hard to Change. American Educational Research Journal, 31(3), 453-479. http://dx.doi.org/10.3102/00028312031003453

Vescio, V., Ross, D., \& Adams, A. (2008). A review of research on the impact of professional learning communities on teaching practices and student learning. Teaching \& Teacher Education, 24(1), 80-91.

\section{Notes}

Note 1 . These are as follows: To express oneself orally, the ability to read, numeracy, the ability to express oneself in writing, and the ability to use digital tools.

Note 2. The EFA used Principal Component analysis as the extraction method and Varimax as the rotational technique.

\section{Appendix A}

An overview of the items included in the five scales:

School leadership

"The leadership at this school pays attention to new pedagogical ideas"

"The leadership at this school prioritises which educational initiatives ought to be implemented"

"The leadership at this school follows up on teachers' teaching"

"The leadership at this school arranges for the pedagogical development work"

Teacher collaboration

"The teachers work well together"

"The teachers engage in informal conversations about different perspectives on teaching (e.g., during breaks)"

"Collaboration between the teachers contributes to new perspectives on teachers' teaching"

"It is accepted to bring in creative ideas among the teachers" 
School-based curricula

"The school-based curricula are important in the planning of my teaching"

"Specifying the school-based curricula has been useful for achieving a better understanding of the competency aims"

"Specifying the school-based curricula has been useful for achieving a better understanding of the basic skills"

Teachers' general orientations towards change

"I frequently initiate teaching projects on my own in order to develop my teaching"

"I am good at implementing new pedagogical ideas in my teaching"

"I frequently renew the subject content in my teaching"

"I carry out teaching projects that are introduced at the school"

Reform changes

"KP06 has made me practice new ways of organising the pupils in the classroom"

"KP06 has made me practice new working methods in the classroom"

"The focus on the basic skills in KP06 has brought about changes in the way I teach"

"The competency aims embedded in KP06 are important tools in the planning of my teaching"

"KP06 has altered my attitudes towards the concepts of education and teaching"

\section{Appendix B}

Table 4. Exploratory factor analysis (EFA). Component loadings for Principal component analysis with Varimax rotation

\begin{tabular}{|c|c|c|c|c|c|}
\hline \multirow[t]{2}{*}{ Variable } & \multicolumn{5}{|c|}{ Factor } \\
\hline & 1 & 2 & 3 & 4 & 5 \\
\hline School leadership 1 & .726 & & & & \\
\hline School leadership 2 & .774 & & & & \\
\hline School leadership 3 & .826 & & & & \\
\hline School leadership 4 & .815 & & & & \\
\hline Teacher collaboration 1 & & .700 & & & \\
\hline Teacher collaboration 2 & & .754 & & & \\
\hline Teacher collaboration 3 & & .790 & & & \\
\hline Teacher collaboration 4 & & .711 & & & \\
\hline School-based curricula 1 & & & .800 & & \\
\hline School-based curricula 2 & & & .914 & & \\
\hline School-based curricula 3 & & & .874 & & \\
\hline Teachers' general orientations towards change 1 & & & & .732 & \\
\hline Teachers' general orientations towards change 2 & & & & .787 & \\
\hline Teachers' general orientations towards change 3 & & & & .764 & \\
\hline Teachers' general orientations towards change 4 & & & & .645 & \\
\hline Reform changes 1 & & & & & .840 \\
\hline Reform changes 2 & & & & & .880 \\
\hline Reform changes 3 & & & & & .784 \\
\hline Reform changes 4 & & & & & .565 \\
\hline Reform changes 5 & & & & & .774 \\
\hline
\end{tabular}

$\mathrm{N}=738$. Values below .3 are suppressed.

To produce standard errors (SEs) and confidence intervals (CIs) for the scales in the final model (Figure 5), a bootstrap analysis was conducted in AMOS to estimate approximate the SEs and CIs for the total and indirect 
effects. This procedure required complete data; therefore, the analysis of the standardized total and indirect effects between the scales was based on an imputed data set. An expectation maximization (EM) imputation was carried out using SPSS 20. The EM algorithm replaces missing values with the predicted scores from a series of regression equations in which each missing value is regressed on the remaining observed variables for case $i$ (Enders, 2001).

Table 5. Standardized total and indirect effects between the latent variables in Figure 5

\begin{tabular}{lllll}
\hline Latent variable & Total effect & SE & Indirect effect & SE \\
\hline Reform changes & & & & \\
Teachers' general orientations towards change & $.264^{* * *}$ & .049 & - & - \\
Teacher collaboration & .040 & .027 & .040 & .027 \\
School-based curricula & $.321^{* * *}$ & .052 & .037 & .016 \\
School leadership & $.211^{* * *}$ & .028 & $.211^{* * *}$ & .028 \\
Teachers' general orientations towards change & & & & - \\
Teacher collaboration & $.150^{* *}$ & .059 & - & - \\
School-based curricula & $.139^{* *}$ & .056 & - & .039 \\
School leadership & $.370^{* * *}$ & .045 & $.132^{* *}$ & \\
Teacher collaboration & & & & - \\
School leadership & $.511^{* * *}$ & .040 & - & \\
School-based curricula & & & & \\
School leadership & $.400^{* * *}$ & .043 & - & \\
\hline
\end{tabular}

$* * \mathrm{p}<.05 ; * * * \mathrm{p}<.005$. Results based on the EM imputed dataset using bootstrap (1,000 samples).

\section{Copyrights}

Copyright for this article is retained by the author(s), with first publication rights granted to the journal.

This is an open-access article distributed under the terms and conditions of the Creative Commons Attribution license (http://creativecommons.org/licenses/by/3.0/). 